\title{
Reinterpreting the Israeli-Palestinian Conflict: A Constructivism Theory of Understanding a Cross-Ethnic Phenomena
}

\author{
Mehrzad Javadikouchaksaraei ${ }^{1}$, Mohammad Reevany Bustami ${ }^{1}$, Azeem Fazwan Ahmad Farouk ${ }^{1}$ \& Ali Akbar \\ Ramazaniandarzi ${ }^{1}$ \\ ${ }^{1}$ Center for Policy Research and International Studies, Universiti Sains Malaysia (USM), Penang, Malaysia \\ Correspondence: Mehrzad Javadikouchaksaraei, Center for Policy Research and International Studies, Universiti \\ Sains Malaysia (USM), 11800 Penang, Malaysia. E-mail: mehrzadarian@yahoo.com
}

Received: January 19, 2015 Accepted: April 21, 2015 Online Published: June 13, 2015

doi:10.5539/ass.v11n16p107 URL: http://dx.doi.org/10.5539/ass.v11n16p107

\begin{abstract}
This study proposes the use of constructivist analysis approaches to analyze Israel's policies toward the Palestinians. Constructivism theory is important for understanding the Israeli-Palestinian conflict. The building of a social-political reality can determine the trajectory of protests and violence in the Israeli-Palestinian conflict in the past 60 years in direct association with the crystallization of nationalism and national identity. This paper analyses and explains the Israeli-Palestinian relations through the international relations theory in constructivism and elucidates in depth the reasons for the current struggle in the historical context and the concept of identity.
\end{abstract}

Keywords: constructivism, conflict, Israel, Palestine

\section{Introduction}

In the field of international relations (IR), constructivism theory has stood strong for a number of reasons. These reasons include the limitations of realism and liberalism. The constructivist viewpoint has explanatory capacity and power through which the issues that arose post $9 / 11$ can be successfully addressed. In situations when decisions contradict conventional rationality, constructivism plays an important role in determining interests through norms and identity of specific ethnic groupings within and across nations.

Constructivism has progressed to define the modification in IR, particularly on identity factors and norms. This change in scope was possible towards the end of the 1980s and the beginning of the 1990s due to the studies by Ounf (1989), Wendt (1992), Finnemore (1996), and Katzenstein (1996). The article by Finnemore and Sikkink (1998) entitled "International Norm Dynamics and Political Change" published in the International Organization further promoted the ideas of constructivism. Similar articles were written by Kubalkova, Onuf, and Kowert (1998) entitled, "International Relations in a Constructed World" and Wendt (1999) entitled "Social Theory of International Politics". Constructivism posits the idea that the world is a social construction; hence, norms and identities of social groupings are crucial in understanding this constructed world. In actuality there is arguably an ontological overlap between realism and constructivism whereby realism recognizes issues related to internal dynamics including those related to people, cultures and identities, even more so with communities of neighbouring nations (Ali \& Bustami, 2014).

In the context of this article, social theory, which is the root of constructivism, offers a theoretical background of life and social change. Related to people, the word "Hebrew" is associated with the early Israeli Kingdom. However, whether by birth or through conversion, Jews are regarded as belonging to an ethno-religious group (Moore, 2008). In international political theory, the state is regarded under constructivism as the main units of analysis. In contrast with theory of realism, constructivism does not concentrate merely on the material feature but rather considers the associations of many actors together with the institutions present in a particular state (Wendt, 1994).

The focus of constructivism is on the social interpretation of reality (Alder, 1997). Campbell (1922) indicated that the construction of a threat is caused by the discrimination of a community from an intimidating "other", thereby creating a boundary amongst the communities. Palestinian identity surfaced largely because Jewish immigrants were threatened. Indeed the concept of boundaries and cross-boundary conflict are in and of themselves social constructions based on national and ethnic norms and identity; hence, to a large extend the 
Israel-Palestninian conflict is a cross-ethnic phenomena anchored on identity. This identity played an important role in the Palestinian dispute (Campbell, 1922). The British government authorized Palestine, whereas the League of Nations authenticated the legal charge for the administration of Palestine and released the Balfour Declaration in 1917. The League of Nations also pledged a Jewish 'national home' in Palestine to European Zionists (Liqueur \& Rubin, 1985). Many Arab thinkers and liberals were inspired by this further presence and visibility of the West. People who spoke Arabic began to regard themselves as a set of unique "Arab" people who possessed the right to an independent statehood because these people had greater strength and regarded themselves in a different way (Khalidi et al., 1991).

The theory of constructivism considers the social theory of knowledge, implying that all concerned actors or players necessarily participate when a disagreement or a problem exists. Contrary to the theory of realism, constructivism does not accept the individualistic approach and the theory of action as an absolute; rather, it describes the analysis of power. Constructivist theorists believe that the difference between the levels of observation and action, and the spontaneous connection between the two levels are significant (European Journal of International Relations, 2000).

\section{Literature Review}

Identifying the theory of IR is not easy despite the significance of constructivism in IR because various studies can be classified as constructive in nature. A number of these studies aim at identifying constructivism within the theoretical framework of the IR. Reus-Smit \& Katzentein (1996); Ruggie (1998) \& Keohane (1999) have also stated that the formation of constructivism opposed neoliberal intuitionalism and neorealism, a theory that has been discussed by both constructivists and rationalists. Alder (1997) posited that constructivism as a compromise between rationalism and traditionalism, based on positivism and other kinds of extreme theories involved in the study of the international systems (Katzenstein \& Krasner, 1998; Ruggie, 1998; Price, 1998).

It is argued that constructivism excludes the methodological or conceptual framework required to perform an effective empirical study, but no alternate research plan has been created. This exclusion has lent support to the thinking of the constructivists engaged in the study of IR (Hopf, 1998; Reus-Smit, 1996). However, this thinking is incorrect. Many researchers on the topic concentrate on diverse ideas, leading to differences between them. Nevertheless, constructivists viewed as second-generation critical theorists allow epistemological, methodological, ontological, and normative classification of their opinions (Reus-Smit, 1996). Yet, Zehfuss (2002) stated that although constructivism has been studied, described, and tested, its theory remains unclear.

Certain constructivists have studied the importance of the rules and standards for the creation of reality, whereas others have concentrated on the concepts of identity and intersubjective practices (Katzenstein, 1996). These studies were complicated, leading some researchers to opine that constructivism is merely a general guideline used to study relevant topics (Kratochwil, 1989; Wendt, 1999). However, this view creates certain problems in the study of constructivism (Katzenstein, 1996). Many different classifications have been developed for the study of constructivism, with several researchers focusing on its different aspects, such as the security of communities, political economy, and the development and nature of national interest (Adler, 1997).

Constructivist literature has three main ontological ideas. These ideas emphasize the significance of the additional or normative and the material structures. They also focus on the constitute interests and actions and emphasize on the mutually constituted nature of the agents and structures (Price \& Reus-Smit, 1998; Adler, 1992). These are related to actual communities, be they ethnic, cultural or religious. Constructivists use various scientific methods, but the use of multiple ways of dealing with subjects. Normally, the interpretative approach is used in studies involving constructivism. Critical theorists question the ideas of human nature and action, and emphasize the importance of social construction of interests and actions. Constructivists do not support value-neutral theories, but rather prefer theories that aim at clarifying the structures of domination (Adler, 1997). The power is a concern for constructivists.

In problematizing the Israeli-Palestinian conflict, it is crucially important to understand the social reality from the point of views of the social actors themselves. For without an insight of the subjective reality informed by the Israeli and Palestinian people themselves, the analytical framework would be merely a super-imposed reality as perceived by researchers, which may or may not reflect the reality agreed or accepted by the social actors themselves (Israeli and Palestinian people). This is the essence of construtivism.

Within this rationality lies the objective of this article. The struggle, the experiences and the root causes of the conflict is to be understood as a social contruction of reality. The articles posits a line of reasoning which argues that the connection between the symbolism, be they ethnic, cultural or religious, and the structures by social and political actors are essential in analyzing and contextualizing this decade-long conflict. The characters, attitudes 
and interests of those involved are of equal importance as the sequence of events. The implication can be that the parties in this conflict ought to mutually understand each other's wishes in order to reach a level of confidence-builidng which is more likely to lead to peaceful resolution of the relations, as prescribed by the constructivist paradigm.

Reevany Bustami and Ellisha Nasruddin argued that the process of theorizing ought to be a dynamic one" in that knowledge-building and research should be able to explain or challenge theories in three ways. It should "be able to (1) use theories in order to formulate conceptual framework, (2) study the evidence on the ground nd identify new patterns to be the basis of theory formulation, and (3) explore the perceptions and the meanings of the social actors to capture the reality as constructed by them and their interaction." (Malaysian Studies, 1999, p. 119, Vol. XVII, No. 2).

\section{Discussion}

\subsection{Constructivist Interpretation of Conflict and Peace-building}

Many researchers consider the idea of constructivism to be a basis for describing the factors affecting IR and countries. Constructivists believe that the identity, interest, and behavior of the states are determined by certain standards, and that states can modify these standards by changing their behavior and identity. Conflicts and peace missions are influenced by both identity and norms (Katzenstein, 1996; Paris, 1995).

However, new standards have to be established for peace missions, and ensuring peace is linked to constructivist logic. Destroyed states need to be rebuilt according to the standards acknowledged by all those involved in the rebuilding process. Furthermore, an identity crisis leads to conflicts and debates on the codes of conduct. This debate can lead to a change in the codes involved.

The realist theory differs with the ideas of the constructivists in that realists espouse the idea that conflicts are not constructed, but rather are intrinsic and determined by historical and objective factors. These factors cause confrontation between states. An ethno-realist interpretation, which was conducted recently, called for a traditional description of the conflict between the states to enhance understanding. Ethnic rivalries are usually based on security concerns and absence of trust, causing states to use military strength to increase security, which in turn generates confrontation between different states (Zehfuss, 2002).

People who support the democratic model, known as democratizers, are in favor of the constructivist way of doing things. They focus on the concepts of justice, democratization, the role of the international community in the rebuilding of states, and the establishment of their identities. They also favor human rights (Strazisar, 1998). Such kind of institutions set standards without considering the interests and ambition of the states.

Constructive resolution is usually prone to being held if contradictory get-togethers could reform their own perception of their own target along with the clash. This approach will assist in ensuring that norms, ideals, admiration, trustworthiness, and values are respected and that common grounds are identified to find resolutions. Effective clash administration also requires abilities as well as expertise to establish and maintain effective working relationships resulting in trouble dealing and decision-making (Deutsch, 2000).

\subsubsection{Constructivism Vision and View of the Israeli-Palestinian Conflict}

"Constructivism seizes the middle ground because it is interested in understanding how the material, subjective and intersubjective worlds interact in the social construction of reality, and because, rather than focusing exclusively on how structures constitute agents' identities and interests, it also seeks to explain how individual agents socially construct these structures in the first place". Constructivism provides a complete infrastructure to understand the resulting issues and changes of the conflict to cooperation.

The constructivist approach further explains the factors related to the Israeli-Palestinian-Arab issue. Constructivism espouses the idea that the social environment creates a definition of the people as their social identity (Risse, 2005). Today, people living on 'Israeli land' are considered Jews, whereas the Jewish law defines a Jew to be a person born in a Jewish family or a person who has converted to Judaism. The idea of constructivism lies in social theory and provides a thorough composition of change and life with respect to social circumstances. "Hebrew" refers to people associated with the old Israeli Kingdom. By contrast, Jews are known as those who are ethno-religious, and those may not have been born Jewish, but opts to convert to Judaism (Moore, 2008).

Constructivism also analyzes the overall means and ways the political characters perceive and exhibit the material and social world. The claim to have a separate identity-based state of the Jewish Zionists and the Arabs in Palestine is founded on the insecurity of being a minority group in their very own land and the connection 
between religion and land. Different identities have different treatments. For example, some privileges may be wrong and offensive to another identity and its group. With this diversity, human agents such as political groups and leaders actively assess activities associated with languages, ideas, ethnicity, among others and attempt to make the conflict of the social world meaningful (Strazisar, 1998). Generally, the elites misused the perceived beliefs of the Jewish community that emphasized the significance of the messianic land and its traditions. They stressed that people like them need to continue the promise of populating the land.

Constructivism also focuses on building, understanding, and exploring social reality (Alder, 1997).The emergence of the Palestinian identity because of the presence of Jewish immigrants and its associated threat plays a very significant role in the birth of the Palestinian conflict (Rubin, 1985). People were more determined to have a different place for themselves. People who spoke Arabic identified themselves as "Arab" people (Khalidi, 1991). However, clear evidence that a community is threatened by another community is needed. This requirement serves as the boundary between communities in the subject and the threat outside. The Balfour Declaration was issued by the British mandate for Palestine in 1917. This mandate stood as a legal commission to administer Palestine and served as a promise to the European Zionist for a Jewish home in Palestine as their nation. Such an influence and dominance of the West affected the activists of the Arabs as well (Campbell, 1922).

According to scholars, ethnicity and religion are two different aspects. However, Judaism does not follow this idea because of its social environment (Boyarin, 1994). Despite this fact, the Jewish identity plays a significant role, bounding religion and land in subjective conflict. The Hebrews underwent many changes with respect to their social environment in more than 3,000 years before the Western culture and religion emerged. During this period, these people, now referred to as Jews, were the subject of anarchy and slavery, as well as theocratic conquest, exile, self-government, and occupation (Lipschits \& Blenkinsopp, 2003; Sammy, 2015). According to Daniel Boyarin, the idea of Jewishness is very chaotic with respect to identity because being Jewish is not religious, national, or genealogical, but a mixture of all (Ibid). The Jews, during the diaspora, interacted with and were greatly influenced by Persian, Babylonian, Hellenic, and Egyptian cultures. Examples also include the nationalism movement (Anderson, 1989) that later caused the Jewish state formation in the Levant.

Several Jewish leaders progressed in the social world and left a lasting impression on people as to their identity. An interest was gradually seen to rise in the state operating environment (Risse, 2005). Hence, excluding religion, the political and social conditions in their environments were serious with respect to an Israeli state and its achievement. While the accomplishment of the statehood was seen, the presence of Palestinians locals became under a critical question, thereby starting the subjective conflict. The identity of the Palestinians and their land were threatened because of Jewish immigration, and identity is a very significant issue with respect to the conflict (Yanacopulos, 2006).

Constructivism is also useful because of its consideration of the social patterns of human interaction, and the means and widespread ideas on reality held by people that promote behavior, norms, and regulations (Lundquist, 1987). Norms and regulations likely to be distributed and widespread can be summarized collectively as inter-subjective elements (Finnemore, 1996). Furthermore, constructivists emphasize the identity that groups hold socially. The Israeli-Palestinian-Arab conflict is most favorably rationalized because of the presence of a clear evidence of identity threat in this philosophy. The theory of constructivism deals with the dominant model and assesses the causes of the political actors opting for different meanings with respect to reality (Risse, 2005).

To deal with it, studying, and considering the current and past conditions of the people of the subjective region is important. Analysis of the present and past state of affairs between Palestine and Israel is also very significant. Reaching a resolution will not be easy unless both conflicting parties discuss their significant issues and understand the other's wishes (Yanacopulos, 2006). The Palestinian Arabs consider the rise in the Jewish population and their dominance in Palestine as a major threat to their identity and race; hence, protests and outbreaks are made against immigrant Jews. This idea of Jewish threat was arguably the sole cause of many Arab Nationalist Movements that opposed the Jewish Zionist movements and supported religious and political motives. The true nature of the issue must be understood if a consensus is to be reached. The actions to be taken should be collective to end the conflicts. It is within this framework of understanding and inclusiveness that "religious, ethnic and cultural diversity" and resolutions of differences can be addressed (Reevany et al., 2005). According to constructivists, the emphasis should be on the differences of people and its effects on relationships. (Weldes, 1996). Discussions done separately would result in more conflicts and no negotiations would be drawn. Although international mediators have adopted the constructivist approach in solving the conflict through different agreement and accords, the issue has yet to be settled (Alder, 1997). 
To reiterate, the focus of this article is to analyze the root cause of the conflict through constructivism. Identity is a very significant factor in the subjective conflict because identity distinction rationalizes the demand for political leaders and ownership of the land. A distinct and culturally acceptable identity is important in establishing a nation. Distinct ethnic identity and religious notions also play very influential roles in the gaining of statehood. These ethnic identity distinctions and boundaries establish the justifications. This leads to the cross-ethnic phenomena at the heart of the conflict. The notion of religion legitimizes claims of ownership, which leads to conflicts. The Jews are referred to as Hebrews or Israelites with a specific identity. Even during their exile, they consistently maintained their identity. Their perception of religion also lies on the notion of a state of God's people. The Jewish people believe that the arrival of "The Messiah" means they need to reclaim their homeland. Indeed spirituality and religious beliefs and conviction can play a significant and long-lasting role in defining identity and trajectory of boundaries, culturally and geographically, as it did in Southeast Asia (Bustami et al., 2012). Using and exploiting this belief, the leaders of Jewish groups associate this religious identity with land and justify their aims of building a nation. Hence, they want to build a nation in God's name in accordance with their views and mindset. The current leader of Zionism, Theodor Herzl, is often heard echoing the opinion of one of the founders of the movement, Israel Zangwill. He opines that Palestine is a place "without a people for a people without a land" (Pappe, 1994). An important observation is that Herzl and Zangwill did not consider the population of Palestine. However, the presence of Palestinians was dominantly felt when the Jewish settlers bought lands.

According to the Zionist leaders, their scriptures mentioned Palestine as their long-lost land by their God; hence, taking advantage of the Palestinian Jews living there, the leaders took this factor to encourage the huge immigration of the Jews in the land and fill it with their population. In 1948, Israel was finally a nation, giving rise to the emergence of the subjective debate. This loss of Palestine is looked upon as a reminder of the glories the Arabs had, since the Arab world seems to be in decline presently (Weldes et al., 1999). This being said, the Arab states believe that they failed to serve their fellowmen that is the Arabs of the Palestine (Lesch \& Tessler, 1989). This resulted in the emergence of propagandas to support the distinct identity of Palestine, which was nothing different than what the Israelis claimed as their own distinct identity. This, consequently, explains the emergence of the conflict of identities and recognition (Weldes et al., 1999).

\section{Conclusion}

Constructivism assesses the combined understanding and methods of political actors in connecting symbolism that structures the material and social worlds; thus, they normally constitute the characteristics, attitudes, and interests of political actors. Constructivists (Alder, 1997) concentrate on the disparities between people and the way these associations are constructed with the help of mutual social institutions. The cross-ethnic, cross-cultural and cross-community disparities ought to be analyzed in order to fully comprehend the totality of the conflict phenomena. If not, the alternative can lead to futility. Many agreements and treaties have been signed, and conditions have been set by the international peacekeepers who utilized the constructivist approach, however, all their efforts were futile (Finnemore, 1996). The present disagreements between Israel and Palestine will only intensify if no individual discussions and dialogues occur. The present and previous conditions of Israel and Palestine, including their behaviors are important considerations. That the opposing parties are mutually gathered and each party comprehends each other's wishes, as suggested in the constructivist strategy of resolving clashes, is of great significance for the solution to this conflict (Yanacopulos, 2006). Ultimately, despite belonging to different groups, religion, ethnicity, and culture, Israelis and Palestinians have a common and shared destiny.

\section{References}

Adler, E. (1997). Seizing the Middle Ground: Constructivism in World Politics. European Journal of International Relations, 319-330-363. http://dx.doi.org/10.1177/1354066197003003003

Andersen, F., \& Freedman, D. N. (1989). Amos: A New Translation with Introduction and Commentary. Anchor Bible 24A. New York.

Baylis, J., \& Steve, S. S. (2001). The Globalization of World Politics: An Introduction to International Relations (p. 247). Oxford: Oxford University Press.

Bustami, R. M., \& Nasruddin, E. (1999). Towards A Reorientation of Theory and Research on Development in Malaysia: A Critical Evaluation of Current Ontological and Epistemological Assumptions. Journal of Malaysian Studies, XVII(2), 119. USM Publications, Penang.

Bustami, R. M., Nasruddin, E., \& Hussin, Z. (2005). Religious Pluralism, Islam and the New Malaysian Prime Minister's Ethnical Rationality. In Possibilities of Religious Pluralism Goran Collste Linkoping Studies in 
Identity and Pluralism (pp. 31-47). Linkoping University Press, Sweden.

Bustami, R., Bustami, R. M., \& Badrin, H. (2012). Spiritualiti dan Gerakan Sufi dalam Diaspora Melayu: Satu Analisis Penerokaan Tariqa Ahmadiyya. In Prosiding Seminar Antarabangsa Perantauan Sumatera-Malaysia Muhammad Salleh and Jamilah Hani Esa. Centre for Policy Research and International Studies, USM, Penang, Malaysia.

Campbell, D. (1998). Writing Security: United States Foreign Policy and the Politics of Identity (Revised Edition). Minneapolis, University of Minnesota Press.

Deutsch, K. W. (2000). Political Community at the International Level. ECKO House Publishing, USA

Finnemore, M. (1996). Constructing Norms of Humanitarian Intervention. In P. J. Katzenstein (Ed.), The Culture of National Security: Norms and Identity in World Politics. New York, Columbia University Press.

Finnemore, M., \& Sikkink, K. (1998). International Norm Dynamics and Political Change. International Organization, 52, 4-22. http://dx.doi.org/10.1162/002081898550789

Hopf, T. (1998). The Promise of Constructivism in International Relations Theory. International Security. Journal of European Public Policy, 12(2), 291-309.

Katzenstein, P. (1996). Introduction: Alternative Perspectives on National Security, The Culture of National Security: Norms and Identity in World Politics (pp. 1-32). New York: Columbia University Press.

Katzenstein, P. (1996). The Culture of National Security: Norms and Identity in World Politics. New York: Columbia University Press.

Khalidi, W. (1971). From Haven to Conquest: Readings in Zionism and the Palestine Problem Until 1948. Beirut, The Institute for Palestine Studies.

Kowert, P., \& Legro, J. (1996). Norms, Identity, and T heir Limits: A Theoretical Reprise. In P. J. Katzenstein (Ed.), The Culture of National Security: Norms and Identity in World Politics. New York, Columbia University Press.

Kratochwil, A. (2010). Imposing coherence international relations and science. Journal of International Relations and Development, 13, 301-322. http://dx.doi.org/10.1057/jird.2010.11

Kratochwil, F. (1989). Rules Norms and Decisions: On the Conditions of Practical and Legal Reasoning in International Relations and Domestic Affairs. Cambridge, Cambridge University Press. http://dx.doi.org/10. 1017/cbo9780511559044

Lipschits, O., \& Blenkinsopp, J. (2003). Judah and the Judeans in the Neo-Babylonian Period. Winona Lake: Eisenbrauns.

Maksum, A., \& Bustami, R. M. (2014). Ketegangan Hubungan Indonesia-Malaysia dalam Isu Tarian Pendet. Journal of Malaysian Studies, 32(2). USM Publications, Penang.

Maksum, A., \& Bustami, R. M. (2014). Ketegangan Hubungan Indonesia-Malaysia dalam Isu Tarian Pendet, Journal of Malaysian Studies, 32(2). USM Publications, Penang.

Moore, D. (2008). American Jewish identity politics. University of Michigan Press, USA.

Morris, B. (2001). Righteous Victims: A History of the Zionist-Arab Conflict (p. 303). New York: Vintage Books.

Onuf, N. (1998). Constructivism: A user's manual. International relations in a constructed world (pp. 58-78), New York, M.E. Sharp.

Pappe, I. (1994). The Making of the Arab-Israeli Conflict.

Paris, R. (1999). Constructing Liberal States: I.R. Theory and Post-Conflict Peace-building. Paper presented at the annual meeting of the International Studies Association, Washington.

Posen, B. (1993). The Security Dilemma and Ethnic Conflict. In M. Brown (Ed.), Ethnic Conflict and International Security (p. 103). Princeton: Princeton University Press. http://dx.doi.org/10.1080/00396 339308442672

Reus-Smit, C. (1996). The Constructivist Turn: Critical Theory after the Cold War. Canberra, Australia: Department of International Relations, Research School of Pacific and Asian Studies, Australian National University.

Reus-Smit, C. (1998). Dangerous Liaisons? Critical International Theory and Constructivism. European Journal of International Relations. 
Risse, T. (2005). Neo-functionalism, European Identity and the Puzzles of European Integration (pp. 291-309).

Robert, O., \& Krasner, S. (1998). Theory and Constructivism. European Journal of International Relations International Organization and the Study of World Politics.

Ruggie, J. (1998). International Organization, Constructing the World Polity. Essays on International Institutionalization, London and New York, Routledge.

Sammy, R. (2015). The Emergence and Evolution of Palestinian Nationalism. International Journal of Multicultural and Multireligious Understanding, 1-7

Strazisar, N. (1998). Rethinking the Concept of Peace-building: The Case of Bosnia and Hercegovina (p. 109). Paper presented at the annual meeting of the International Studies Association, Minneapolis.

Wendt, A. (1992). Anarchy is what States Make of it: The Social Construction of Power Politics. International Organization, 385. http://dx.doi.org/10.1017/S0020818300027764

Wendt, A. (1999). Social Theory of International Politics (pp. 17-22). Cambridge University Press. http://dx.doi. org/10.1017/cbo9780511612183

Yanacopulos, H., \& Hanlon, J. (2006). Civil war, civil peace (pp. 25-26). James Currey Publishers.

Zehfuss, M. (2002). Constructivism in International Relations: The Politics of Reality (p. 7). Cambridge, Cambridge University Press. http://dx.doi.org/10.1017/cbo9780511491795

\section{Copyrights}

Copyright for this article is retained by the author(s), with first publication rights granted to the journal.

This is an open-access article distributed under the terms and conditions of the Creative Commons Attribution license (http://creativecommons.org/licenses/by/3.0/). 